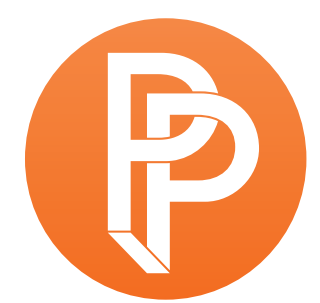

PERFORMANCE

PHILOSOPHY

\title{
THE PARADOX OF A GESTURE, ENLARGED BY THE DISTENSIONOF TIME: \\ MERLEAU-PONTY AND LACAN ON A SLOW-MOTION PICTURE OF HENRI MATISSE PAINTING
}

ASTRID DEUBER-MANKOWSKY RUHR UNIVERSITY BOCHUM

TRANSLATED BY MARKUS HARDTMANN

In his 1964 series of lectures, The Four Fundamental Concepts of Psychoanalysis, Jacques Lacan briefly mentions a "delightful example" $(1981,114)$ that Maurice Merleau-Ponty had given in an excursus to his book, Signs (1964c, 45-6). Lacan describes it as "that strange slow-motion film in which one sees Matisse painting" (114). What the psychoanalyst is referring to is a scene in the documentary Henri Matisse by François Campaux, a 16-mm black-and-white sound film from 1946.

Lacan mentions Merleau-Ponty's interpretation of the filmic example only in passing. This reference, however, is anything but arbitrary, for it marks the conclusion of an intense altercation he had with the aesthetics of perception and ontology of Merleau-Ponty, who had passed away three years earlier. Lacan had been friends with the philosopher since the early 1940s (Roudinesco 1997, 210). Seven days after Merleau-Ponty passed away, Lacan expressed his grief on May 10 , 1961, to a full auditorium with the following words:

It was a heavy blow to us. [...] I can also say that because of this mortal fatefulness, we will not have had time to bring our formulations and statements closer together. (cited in Roudinesco 1997, 280; translation modified M.H.) ${ }^{1}$ 
The differences alluded to by Lacan refer to an intervention by Merleau-Ponty at a congress in Bonneval in the autumn of 1960. At the meeting, Lacan defended his thesis that the unconscious is structured like a language against the advocates of a phenomenological Freudianism. Lacan is said to have counted on Merleau-Ponty's support, but the latter rejected Lacan's thesis as totalitarian (Roudinesco 1997, 254; also see Lacan 1981, 71).

How strongly Lacan felt about the need for a clarification of their respective positions can already be seen from the short article that he wrote as an homage to Merleau-Ponty in 1961, published in a special issue of the journal Les temps modernes dedicated to the philosopher. In Merleau-Ponty's last published article, "Eye and Mind" (first published 1961; written July 1960), in particular, and especially in the remarks on painting developed therein, Lacan saw a point of connection between their respective positions. Thus Lacan declares his agreement with Merleau-Ponty's view that there is a reality at work in painting that affords it a truth function sui generis. Lacan emphasizes the fact that painting is the truth function of a reality that cannot be captured physically and has to remain invisible for the natural sciences.

In the following discussion of how Merleau-Ponty and Lacan refer to the filmic example showing Matisse painting, I will not seek to reconstruct Lacan's altercation with Merleau-Ponty. Rather, I would like to pursue the following two questions: First, I will reconstruct the different ways in which Merleau-Ponty and Lacan determine, in their respective discussions of the recording of Matisse painting, the mediality of gesture in the constitution of the subject. Merleau-Ponty raises the question of an ethics of gesture by situating the subject in the field of tension between rationality and the presence of bodily experience: gesture establishes the link to the reality of the creative act and leads to "this fabric of brute meaning" (cette nappe de sens brut) which, according to MerleauPonty, the "activism [of scientific thinking] would prefer to ignore" (Merleau-Ponty 1964a, 161). ${ }^{2}$ At the same time, gesture functions as a protection against the intellectualiziation (Vergeistigung) that threatens the subject when rationality takes on a life of its own. Lacan takes up the argument at the precise point where Merleau-Ponty, in contradistinction to Platonic philosophy, assumes that we are beings who are looked at, rather than beings looking at the truth of the world in the ideas. That is to say, Lacan likewise starts out from the pre-existence of the gaze-and thus also from gesture. Unlike Merleau-Ponty, however, Lacan does not assume that gesture leads to a "fabric of brute meaning"; for him, it leads to the split of the subject. As I am going to explain in more detail, gesture is characterized, for Lacan, by a paradox that manifests itself as arrest and haste in the dimension of time, and as fissure and suture in the dimension of space. The question of an ethics of gesture also arises for Lacan in relation to the recognition of the limitedness of the subject. Whereas Merleau-Ponty associates the latter with the recognition of the intimacy between mind and body, however, Lacan connects it to the recognition of the split nature of the subject.

What role do the philosopher and the psychoanalyst ascribe to the technical in their critique of an intellectualizing philosophy of mind (Geistesphilosophie)? This is the second question that is going to guide my reflections on the mediality of gesture. After all, the "strange[ness]" (Lacan 1981, 114) of the filmic example is the result of a strategically used technical intervention: slow motion. Do Merleau-Ponty and Lacan take the specific productivity of the technical into account? And if so, how 
do they reflect on it? Do they develop concepts that would allow one to plumb the new, previously unseen, aesthetic spaces that have become possible with technical media of reproduction? Or do Merleau-Ponty and Lacan, in their critique of the philosophy of reflection and substance, ultimately reproduce the very dichotomies of this philosophical tradition? If this were the case, then-and this is will be my final thesis-their approach towards an ethics of gesture would have to be reconsidered.

\section{The Artificiality of Slow Motion}

The film begins with a female model clad in a bright, wide dress entering Matisse's studio-a space suffused with light. The model sits down in an armchair, and the master adjusts her position and arranges her dress a bit. Merleau-Ponty does not mention the gender coding of the scene, while Lacan comments on it only indirectly, along the lines of his psychoanalytic reading. At first, the scene unfolds at the usual speed. The camera wanders from the model to the easel, before focusing on the canvas and the hand of Matisse, who is holding a brush and transferring the outlines of the face and the hair with a succession of deliberate brushstrokes onto the canvas. The scene is set to a movement with much forward momentum from César Franck's wellknown symphony in D minor, and it is accompanied by a voice-over that rushes forth in a similar manner. At the conclusion of the scene, it is repeated, but this time it has been recorded at a much higher frame rate and thus appears in slow motion when it is replayed at normal speed. This shift is also marked acoustically by a change in rhythm. As the voice-over comments, "grace au cinéma," thanks to the technology of cinema, one is able to analyze, in slow motion, the

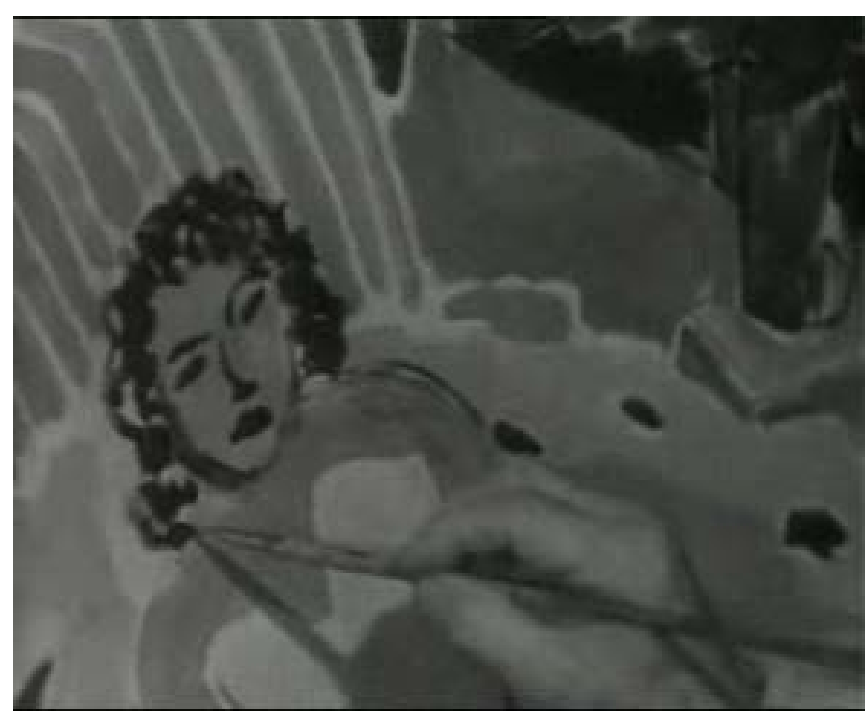

Fig. 1. Still from A Great French Painter, Henri Matisse, a film written and directed by François Campaux (1946). (C) 1946, Michel Valio-Cavaglione / Distribution Argos Films. Showing Matisse's painting Jeune femme en blanc, fond rouge (1947). (c) Succession H. Matisse/ DACS 2017 gestures with which Matisse transfers paint onto the canvas.

Lacan's mention of the scene refers to the description and interpretation of it by Merleau-Ponty, which I would now like to present. Merleau-Ponty introduces the scene with the following words:

A camera once recorded the work of Matisse in slow motion. The impression was prodigious, so much so that Matisse himself was moved, they say. That same brush which, seen with the naked eye, leaped from one act to another, was seen to meditate in a solemn and expanding [dilaté] time-in the imminence of a world's 
creation-to try ten possible movements, dance in front of the canvas, brush it lightly several times, and crash down finally like a lightning stroke upon the one line necessary. $(1964 c, 45)$

As Matisse himself reported, he felt "naked" when he saw the scene showing his gestures. The "strange journey" made by his hand was not, as he emphasized, a sign of hesitation. Rather, he was "unconsciously establishing the relationship between the subject" he was about to draw and the size of the paper (cited in Bois 1990, 46). ${ }^{3}$

While Lacan will highlight the ambivalence expressed in Matisse's look at himself and the movements of his brush and connect this ambivalence to the sovereignty of the unconscious, Merleau-Ponty bases his interpretation on the analysis put forward by the voice-over. In the commentary, the voice-over emphasizes that Matisse's gestures appear carefully considered when viewed in slow motion, as though the artistic act arose from a process of meditating and measuring and were based on an act of reflection, of calculation, and of conscious choice. The important point is that calculation and choice do not need to exclude one another on the level of reflection. Against this backdrop, Merleau-Ponty interprets the gestures circling above the canvas as a scanning of possible lines in order to realize, out of an infinite number of possibilities, the one, optimal line. As Matisse is shown painting in slow motion, he is reminiscent of the God of Leibniz who acts rationally in a particular way: following the rule that the greatest variety of things must be combined with the greatest order, he chooses, out of an infinite number of possibilities, the best one. The choice made by Leibniz' God is not predetermined, but it is nonetheless necessary, and can, at least in principle, be predicted. Merleau-Ponty does in fact compare Matisse filmed in slow motion to the God of Leibniz, who chooses the perfect world among all possible worlds and thereby solves the difficult problem of minimum and maximum. However, Merleau-Ponty adds that Matisse would be wrong if, putting his faith in the film, he assumed that he did indeed proceed like God. This impression is "artificial" and, as Merleau-Ponty makes clear, owes itself entirely to the technology (Technik) of slow motion (1964c, 45).

It is not difficult to recognize in this critique-and in the comparison with Leibniz' God who chooses among infinite options-the critique of the "cybernetic ideology" that Merleau-Ponty formulated in his essay "Eye and Mind." As Merleau-Ponty maintains, cybernetics transforms operational thought into an "absolute artificialism" (artificialisme absolu) and derives "human creations [...] from a natural information process, itself conceived on the model of human machines" (1964a, 160). Cybernetics thus represents, for Merleau-Ponty, an apex of the rationalist tradition. It belongs to a philosophy of pure vision that substitutes an intellectual eye for the perceiving eye, and replaces the world with a model of the world or, as Merleau-Ponty laconically puts it, with its "[b]eing thought" (1964a, 176).

Opposing this cybernetic way of thinking, Merleau-Ponty demands that:

Scientific thinking — that is, a thinking in overflight (pensée de survol), a thinking of the object-in-general-must return to the 'there is' which underlies it; to the site, the soil of the sensible and opened world such as it is in our life and for our body-not 
that possible body which we may legitimately think of as an information machine but that actual body I call mine, this sentinel standing quietly at the command of my words and my acts. (1964a 160-1; translation modified, M.H.)

The body here functions as a sentinel not only against the "overflight" of scientific thinking, but also as a guard protecting the connection between body and life against a technology associated with "artificiality" and the ideology of cybernetics.

When Merleau-Ponty describes the slow-motion film as "artificial," he is not implying that it is fictional. He is suggesting, rather, that it makes us believe that "the painter's hand operated in the physical world (monde physique) where an infinity of options is possible," instead of showing us the event "in the human world of perception and gesture" (1964c, 46). According to Merleau-Ponty's interpretation, slow motion shows Matisse painting from the perspective of rationalist and scientific thinking. In this way, however, the film misses what it purports to analyze: the reality of the creative act. For Merleau-Ponty, the reality of the creative act can only be grasped from the situated, partial perspective of perception, which is conditioned by corporeality. This situated perspective, in turn, is based on the supposition that human beings do not primarily stand opposed to the world; they are, rather, a part of life which, according to Merleau-Ponty, grounds the meaning and the becoming visible of things. How closely related aesthetics and aisthesis are in Merleau-Ponty is shown by his interpretation of art works-and especially images-as "signs for the points of view of seeing" (Wiesing 2000, 274). His philosophy is a kind of Leibnizian Monadology, as it were-a Monadology, however, that does not find its final reason in the vision of God, but posits the belief in perception as the start and endpoint of the questions it pursues. Accordingly, Merleau-Ponty regards the difference between these viewpoints-a difference that is expressed in the style of an image-as the condition for the possibility of generating meaning in painting and language. This, then, is the sense in which one should understand Merleau-Ponty's proposition: "But art, especially painting, draws upon this fabric of brute meaning [sens brut] which [the] activism [of scientific thinking] would prefer to ignore" (1964a, 161).

Despite appearances to the contrary, the painter emerges as a sovereign subject from MerleauPonty's interpretation of the filmic example. His sovereignty, however, is not based on a comparison with a God but relates, instead, to that which connects the painter, through his body, with the "flesh [...] of the world" (1964a, 186): namely, his individual situatedness in space and time. The painter is, according to Merleau-Ponty, "incontestably sovereign in his rumination (rumination) of the world. With no other 'technique' than what his eyes and hands discover in seeing and painting" (161).

As this citation indicates, Merleau-Ponty places the technical on the side of reflection and scientific thinking in his interpretation of the filmic example. He describes both as "artificial," as a thinking in "overflight" (survol). Hence, we can infer that for Merleau-Ponty, "the technical" belongs to the rationalist tradition that he seeks to ground ontologically in the context of his new philosophy. Merleau-Ponty believes that this grounding can be accomplished by means of a "hyper-reflection" 
(surréflexion) that traces reflection and scientific thinking back to an original bond with the world, which is experienced in the corporeality of perception.

This identification of thinking and rationality corresponds precisely to a remark made by MerleauPonty in his well-known lecture "The Film and the New Psychology" (1964d, 48-62). Addressing the relation between cinema-which is after all a technical invention-and Gestalt psychology, Merleau-Ponty affirms that "after the technical instrument has been invented, it must be taken up by an artistic will and, as it were, re-invented before one can succeed in making real films" (1964d, 59). But what are "real films"? For Merleau-Ponty, they are films that make us sense, by means of technology-for instance, through the use of montage-" "the coexistence, the simultaneity of lives in the same world" (55). They are films that "make manifest the union of mind and body, mind and world, and the expression of one in the other" (59). In light of this, the slow-motion film of Matisse painting would have to be described not only as artificial, but also as unreal. For in this scene, technology intervenes in the customary perception of the world and does not adapt to the intimacy of body and mind described by the philosopher.

\section{Small Strokes Raining from the Brush}

Lacan's reference to the "delightful example" occurs at the end of the second part of his lecture series On the Gaze as Petit Objet a, which would become very important in the history of psychoanalytic film theory. In his first lecture on February 28, 1964, Lacan already announces that his discussion of the scopic function would be inspired by Merleau-Ponty's unfinished book The Visible and the Invisible, which had recently been published posthumously (Lacan 1981, 71). With the insight that the idea and philosophical tradition of Idealism had proverbially been guided by the eye, Merleau-Ponty brought to light, according to Lacan, the point at which the philosophical tradition that had begun with Plato's theory of ideas reached its end in the middle of the $20^{\text {th }}$ century (71). Indeed, Merleau-Ponty describes the primacy of perception in his late work in terms of an interrogation already at work in perception itself-that is, in the gaze-rather than only in philosophical reflection (Waldenfels in Burke and Van der Veken 1993, 3). As he maintains, it is "not only philosophy, it is first the gaze that questions things" (Merleau-Ponty 1968, 103).

In this context, Merleau-Ponty's claim that we are not, as Plato would have it, beings who look at the truth of the world in the ideas but, rather, "beings who are looked at, in the spectacle of the world," acquires a particular significance (Lacan 1981, 75). For Lacan, this insight marks the proximity between his own interpretation of the scopic function and Merleau-Ponty's analysis of the eye and the gaze. By showing that we are beings who are looked at, Merleau-Ponty opened up "that new dimension of meditation on the subject that," as Lacan literally puts it, "psychoanalysis enables us to trace" (1981, 82; translation modified, M.H.).

Together with Merleau-Ponty, Lacan assumes the pre-existence of the gaze, but he does not relate it to a scopic point of origin. In his analysis of the phrase "I see only from one point, but in my existence I am looked at from all sides," Lacan instead describes the gaze as a "bipolar reflexive relation" $(1981,81)$. He does not equate the split above which the subject constructs itself with the 
distance between the visible and the invisible. Summarizing the decisive difference to MerleauPonty, Lacan maintains, rather, that the "gaze is presented to us only in the form of a strange contingency" (1981, 72).

To return to the example of the film, Lacan's insistence on the role of contingency in the constitution of the gaze leads him to describe Matisse's brush strokes not as the sovereign gestures of a creative artist, but as "the rain of the brush," as "little strokes raining from the painter's brush" in a particular "rhythm" (1981, 114; translation modified, M.H.). ${ }^{4}$ In a series of strong images that allow the reader to sense the "strange contingency" of the gaze, Lacan then compares the "rain of the brush" with the feathers a bird lets fall, the scales a snake casts off, and the leaves a tree allows to tumble down.

Lacan agrees with Merleau-Ponty's view that it is an "illusion" that every brush stroke by the painter is perfectly deliberate. But the conclusions Lacan draws from this fact are different. According to Lacan, it is not slow motion that is deceptive. Rather, slow motion shows "the paradox of this gesture" - of a gesture, that in its turn seeks to deceptively suggest the "subject is not fully there," but that she is, as Lacan puts it, "remote-controlled (téléguidé)" (Lacan 1981, 115; translation modified, M.H.). With this reference to remote control, Lacan's formulation indicates that the technical will come into play here. Yet in this particular context, the technical has nothing to do with film per se; it relates instead to the scientific status that Lacan accords to the psychoanalytic meditation on the subject.

While Merleau-Ponty denies the scientificity of phenomenology, Lacan follows Freud in holding on to the idea that psychoanalysis is a science. However, the Freudian question of what kind of science psychoanalysis might be is given a new and decisive twist by Lacan: he relates it to the question concerning the origin of modern science as such. As Lacan specifies, the "science in which we are caught up, which forms the context of the action of all of us in the time in which we are living, and which the psycho-analyst himself cannot escape, because it forms part of his conditions, too, is Science itself' $(1981,231)$. In Lacan's reading, it becomes apparent that the concept of science in the modern sense is not older than the concept of the subject, whose truth is the concern of psychoanalysis. Both concepts lead Lacan back, not to Leibniz and the Monadology, but to Descartes, his methodological doubt, and his voluntaristic conception of God. In Lacan's discussion of the history of philosophy, Descartes appears as a precursor to the discovery of the unconscious.

The founder of Rationalism seeks certainty for the subject, as Lacan explains, and at first finds it in the sentence: I doubt, therefore I think. But how could this statement lead to the phrase: I doubt, therefore I am? Or to use a formulation of Lacan's, how could it lead to the sentence: "by virtue of thinking, I am" (De penser, je suis) (1981, 35; 1990, 44)? In order to accomplish this transition, Descartes takes up the ontological proof of God; that is, he infers, from the thinking of man, the thought of God, in whom Being and Thinking coincide. According to Lacan, Descartes thus situates the field of knowledge "at the level of this vastest of subjects, the subject who is supposed to know [le sujet supposé savoir], God" (224; translation modified, M.H.; 1990, 250). And thus Descartes performed, as Lacan comments, "one of the most extraordinary sleights of hand [tours d'escrime] 
that has ever been carried off in the history of mind [l'histoire de l'esprit]." By giving "primacy [...] to the will of God" (225), the founder of modern science put God in charge of eternal truths. In other words, "what Descartes means, and says, is that if two and two make four it is, quite simply, because God wishes it so" (225; 1990, 251).

"I dare to state as a truth," Lacan writes, "that the Freudian field was possible only a certain time after the emergence of the Cartesian subject, in so far as modern science began only after Descartes made his inaugural step" $(1981,47)$. This link between psychoanalysis, science, and the cogito, however, only became apparent in retrospect; that is, after Freud had revised the certainty of the subject. Unlike Descartes, Freud does not assume the existence of an infinite, omniscient substance that would guarantee the eternal truths; on the contrary, Freud demystifies such an assumption as wish-fulfillment. What is certain for Freud, according to Lacan, is that here, "in this field of the beyond of consciousness," there are thoughts, which Lacan in turn interprets as chains of signifiers (44). If Descartes situated the subject at the level of the vastest subject, God, who is supposed to know, Freud locates it in the field of the unconscious. This means that Freud put everyone, including Lacan, in a position to think the subject in relation to the reality of desire.

With this step, Freud in turn transformed the world. If ' $I$ ' is another, then this also affects modern science as it was inaugurated by Descartes. In analysis-Lacan here refers to the psychoanalytic experience-consciousness appears as "irremediably limited" not unlike in Descartes. But in contrast to Cartesian Rationalism, there is, in psychoanalysis, no perfect and infinite being who would offset this limitation. Rather, God is unconscious, as Lacan emphasizes $(1981,59)$. The discovery of the unconscious leads to the realization that God is not the True. The Real that cannot be assimilated is the True, and "the world [...] struck with a presumption of idealization" (81).

The realization that God is unconscious is one side of the scientific character of psychoanalysis. It implies that at the center of our experience is not the relation with an infinite and perfect being, but the "relation [...] with the organ" (1981, 91; translation modified, M.H.) ${ }^{5}$-with the breast, excrement, but also with the eye, among others. This authorizes Lacan to compare the brush strokes of Matisse with the feathers a bird lets fall.

The other side of the scientific character of psychoanalysis results from a fact that Lacan also knows from the analytic experience: namely, the Real "always comes back to the same place" -which is precisely the place "where the subject in so far as he cogitates, where the res cogitans, does not meet it" (1981, 49; translation modified, M.H.). ${ }^{6}$ Regarding the status of psychoanalysis as a science, the decisive question is whether or not this return-which is accidental and oscillates between hazard and fortune-can be operationalized. In other words, it is a matter of basing the randomness of this return of the Real on a scientific foundation that is not deterministic. In this context, Lacan refers to some of the most recent developments in the sciences of his daydevelopments that "demonstrate," as he puts it, "what we can ground on chance." Lacan is well aware that first a limited structuring of the situation is required for this purpose, a structuring "in terms of signifiers [signifiants]" (40). By drawing on mathematical game theory and cybernetics, 
Lacan is then able to reformulate psychoanalysis as a conjectural science of the subject, and thus as a technical discipline.

This reformulation of psychoanalysis proceeds in close contact with clinical experience. Here, in psychoanalytic practice, consciousness does not only appear as irremediably limited insofar as it is instituted as a principle of idealization; it also manifests itself as a principle of misunderstanding and misrecognition-or of méconnaissance. Lacan also refers to this principle of méconnaissance as scotoma, a term used to describe a partial loss of vision, a spot or, precisely, the gaze. And it is, according to Lacan, this spot, this partial loss of vision, this gaze, that Descartes failed to see when he saw the field of knowledge "at the level of this vastest of subjects, the subject who is supposed to know [le sujet supposé savoir], God" (224; translation modified, M.H., 1990, 250).

Yet there are some who, according to Lacan, did see the strange contingency in the geometral image-and thus in the image of modern science and the geometral perspective it created: the painters who were contemporaries of Descartes. As Lacan writes: painters, "above all, have grasped this gaze as such in the mask and I have only to remind you of Goya, for example, for you to realize this" $(1981,84)$. Hence there is a certain complicity between painting and psychoanalysis. Painting and psychoanalysis show that which the geometral dimension elides. Or as Lacan puts it: "If one tries to represent the position of the painter concretely in history, one realizes that he is the source of something that may pass into the real" $(1981,112)$.

In his interpretation of the slow-motion film of Matisse painting, Lacan combines this culturalhistorical justification with the systematic legitimization of psychoanalysis as a conjectural science. Using slow motion as a kind of magnifying lens for time, Lacan explains that "the moment of seeing" (l'instant de voir) can only appear as a suture conjoining the Imaginary and the Symbolic $(1981,118)$. According to Lacan, slow motion makes visible, in every moment of seeing, the self-referential production of a "sort of temporal progress that is called haste, thrust, forward movement" and hides the strange contingency of the gaze (118). From this analysis, Lacan derives the distinction between the gesture, which belongs to the Imaginary, and the act, which pushes forward into the Symbolic. The brush stroke appears as a movement that on the one hand terminates, and on the other hand refers back. It is a motor activity that produces behind itself its own stimulus: the gesture is hesitant. The act, by contrast, is moving forward. According to Lacan, the act is projected forward as haste in the identificatory dialectic of the signifier and the spoken. It is nothing but the first moment of seeing, the Augenblick, the moment of the creation of seeing. The act is the gesture in motion, as Lacan writes, the gesture that is "shown to be seen" (118). The gaze not only terminates the movement, it freezes it. This arrest of the movement, its terminal moment, the interruption, is to be understood, according to Lacan, as a mortification meant to dispossess "the evil eye of the gaze" (118).

To return to the question of the place of the technical in the relation between the aesthetic, knowledge, and the subject, we can say that Lacan uses slow motion as an instrument. From the perspective of the conjectural science of the subject, which is, for Lacan, a technical science, the point of the instrument is to make visible that which remains hidden from "human perception" and 
the empirical sciences. For Lacan, it is not, as Merleau-Ponty maintained, slow motion that deceives; rather, deception appears as the irreducible end of gesture.

Not unlike Merleau-Ponty, however, albeit in a different manner, Lacan also restores the body as a "sentinel" (Merleau-Ponty 1964a 160-1). In Lacan, the body functions as a guard who secures the constitution of the subject in the experience of her central relation to the organ. The construction of the subject proceeds, as Lacan explains, by way of the gesture that materializes on the canvas with the brush stroke and will "always [remain] present there" $(1981,115)$. The trace of the organic left by the gesture on the image-a trace, one might add, that points toward something human, rather than something machinic-is nothing other than the direction of the hand. According to Lacan, this trace of the organic is responsible for the fact that one cannot laterally invert a technical image-for instance, a diapositive-of a painted picture, without its being immediately noticeable. Gesture-which Lacan analyzed with the help of slow-motion technology-thus becomes the stand-in for the alleged centrality of the relation between the subject and the organ.

\section{Gesture and the Technical}

In conclusion, I would like to emphasize that the sentinels of Merleau-Ponty and Lacan do not only protect thought from a flight into metaphysics. They also prevent access to the question of what Walter Benjamin termed in 1936 "a vast and unsuspected field of action [Spielraum]" that the age of reproduction had opened up, through the camera's technical pictures, the close-up, and its use of slow motion ('The Work of Art in the Age of Its Technical Reproducibility': 2nd version [1935], in Benjamin 2008, 37). Although Merleau-Ponty and Lacan accentuate their critiques of the philosophical tradition and the philosophy of the subject differently, their references to the slowmotion film of Matisse make clear that they both continue to think on the basis, and within the conceptual framework, of this tradition. This philosophical tradition, however, does not provide any concepts for the analysis of the potential-and highly specific_productivity of the technical that revolutionizes not only perception, but the very relation between the subject and knowledge.

Probing this new room-for-play would require concepts of technicity and mediality that allow one to think not only the historicity of technology, but also the historicity of perception in its relation to technology. In contrast to Merleau-Ponty and Lacan, Benjamin did not equate technology with rationality. Instead, he outlined a philosophy of technology, which related technology to the way we inhabit and perceive the world and attempted at the same time to conceive of perception as a medium. For Benjamin, film does not depict something, nor does it show an artificial world; rather, it is the result of an "intensive interpenetration" (intensive Durchdringung) of the apparatus and reality $(2008,35 ; 1985,374)$. "The illusionary nature of film is of the second degree. It is", as Benjamin underscores, "the result of editing" $(35 ; 373)$. In this "nature of the second degree" the human being is no longer at the center. Thus I would like to conclude, not with Merleau-Ponty or Lacan, nor with the ethics of gesture that Agamben has in mind, but with Benjamin's proposal to associate gesture with the technical. Benjamin removes gesture from its association with the body or the organ. As I can only outline here, he instead focuses his reflections on the artificial that links gesture with the technical. The starting point of these reflections is Brecht's theater of gesture, 
which links gesture to distance, alienation, and literarization-and thus in an explicit manner to the increasingly technical nature of the lifeworld. Unlike the Futurists, for example, Benjamin conceives of this link in terms of a tender movement: the rhythm of the technical reappears in gesture as a trembling.

In the first version of his manuscript "What is Epic Theatre?" from 1931, Benjamin calls the epic theatre a "literarized theatre" because of its use of posters and lettering, but also because of its use of gestures, which relates epic theatre to Chinese theatre. For Brecht according to Benjamin, in epic theatre it is possible that an actor acts in front of the picture of his character (such as a poster, a projection, an image). The result is that we can no longer know which is the original and which is the copy, what is real and what is performed. Benjamin discusses this approach to epic theatre against the background of the question of how the relation of the gesture to the situation should be understood. Now it must be noted that 'situation' is nothing other than die Lage, which refers to the singular moment, the actual presence. Benjamin answers this question by referring to the "quivering" or "tremulousness of the contours" of the back-projections, which, as he puts it, "suggest the far greater and more intimate proximity from which they (the materialistic ideas) have been wrenched in order to become visible" (Benjamin 1998, 12; see Weber 2008, 104). This "tremulousness of the contours" is the medium in which the dialectics at standstill enfolds (104). ${ }^{7}$

Now it is well known that Adorno (in his letter dated December 17 1934) excitedly praised Benjamin's essay on Kafka. Yet he disagreed with Benjamin's reference to epic theatre. His argument is twofold. First, Adorno writes, Kafka's novels cannot be regarded as a script for epic theatre because they have no audience who could directly intervene into the experiment. Secondly, he writes, the reason why the gesture is important is not to be found in Chinese theatre, but instead in modernity and in the dying away of language. From this he concludes that Kafka's novels are the last and vanishing textual link to the silent movie. In other words, Adorno sees the ambiguity of gesture situated between the sinking into silence with the destruction of language and the rising of language in music. Though Benjamin admitted that Adorno was right in his response, he nevertheless referred to his original thoughts on the experimental character of Kafka's writings in his 1938 letter on Kafka to Scholem. There he admits that Kafka lived in a "complementary world" (1995 112; translation, M.H.) - that is to say, Kafka's experiments were in fact not addressed to an audience that could intervene in the experiment. Nonetheless Benjamin holds on to the idea that the gestures of Kafka's figures are part of an experimental process. ${ }^{8}$ Thus he states that Kafka's gestures of horror benefit from "the fantastic room-for-play, which the catastrophe will not know" (1995, 112; translation, M.H.). ${ }^{9}$

The decisive word here is "fantastic room-for-play." It points back to the second version of the 1936 article on the Work of Art in the Age of its Technical Reproducibility, in which Benjamin relates the turn from representation to experimentation with what he calls second technology and second technology with play. 
1 The French reads: "Nous l'avons reçu en plein coeur. [...] Je puis dire aussi que temps nous aura manqué, en raison de cette fatalité mortelle, pour rapprocher plus nos formules et nos énoncés" (Lacan 1991, 329).

2 The French reads: "Or l'art et notamment la peinture puisent à cette nappe de sens brut dont l'activisme ne veut rien savoir" (Merleau-Ponty 1964b, 13).

3 The passage reads:

Before my pencil ever touched the paper, my hand made a strange journey of its own. I never realized before that I did this. I suddenly felt as if I were shown naked - that everyone could see this - it made me feel deeply embarrassed. You must understand, this was not hesitation. I was unconsciously establishing the relationship between the subject I was about to draw and the size of my paper. (Bois 1990, 46)

${ }^{4}$ The French passage reads:

Au rythme où il pleut du pinceau du peintre ces petites touches qui arriveront au miracle du tableau, il ne s'agit pas de choix, mais d'autre chose. Cet autre chose, est-ce que nous ne pouvons pas essayer de le formuler? Est-ce que la question n'est pas à prendre au plus près de ce que j'ai appelé la pluie du pinceau? Est-ce que, si un oiseau peignait, ce ne serait pas en laissant choir ses plumes, un serpent ses écailles, un arbre à s'écheniller et à faire pleuvoir ses feuilles? (Lacan 1990, 129)

${ }^{5}$ The French reads : "Le rapport du sujet avec l'organe est au coeur de notre expérience" (Lacan 1990, 105).

6 The French reads "Le réel est ici ce qui revient toujours à la même place-à cette place où le sujet en tant qu'il cogite, où la res cogitans ne le rencontre pas" (Lacan 1990, 59).

7 The passage reads:

For as in Hegel, the sequence of time is not the mother of the dialectic but only the medium in which the dialectic manifests itself, so in epic theatre the dialectic is not born of the contradiction between successive statements or ways of behaving, but of gesture itself. (Weber 2008, 104)

${ }^{8}$ Benjamin compares Kafka's literary procedure with gestures with Arthur Stanley Eddington's description of the world from the perspective of the theory of relativity quantum theory in his popular book "Weltbild der Physik".

${ }^{9}$ The German reads: "Seinen Geberden des Schreckens kommt der herrliche Spielraum zu gute, den die Katastrophe nicht kennen wird" $(1995,112)$.

\section{Works Cited}

Benjamin, Walter. 1985a. Gesammelte Schriften. Vol. VI. Frankfurt: Suhrkamp.

___. 1985b. Gesammelte Schriften. Vol. VII. Frankfurt: Suhrkamp.

1995. Gesammelte Briefe. Vol. VI. Frankfurt: Suhrkamp.

1998. "What is Epic Theatre?". In Understanding Brecht, edited by Anna Bostock and Stanley Mitchell, 1-15. London: Verso.

2008. The Work of Art in the Age of Its Technological Reproducibility and Other Writings on Media. Edited by Michael W. Jennings, Brigid Doherty, and Thomas Y. Levin. Translated by Edmund Jephcott, Rodney Livingstone, and Howard Eiland. Cambridge, MA: Harvard University Press.

Bois, Yves-Alain. 1990. Painting as Model. Cambridge MA: MIT Press. 
Lacan, Jacques. 1981. The Seminar of Jacques Lacan: The Four Fundamental Concepts of Psychoanalysis. Edited by Jacques-Alain Miller. Translated by Alan Sheridan. Vol. XI. New York: Norton.

1990. Le séminaire, livre XI: Les quatres concepts fondamentaux de la psychanalyse. Edited by JacquesAlain Miller. Paris: Seuil.

___. 1991. Le séminaire, livre VIII: Le transfert: 1960-1961. Edited by Jacques-Alain Miller. Paris: Seuil.

Merleau-Ponty, Maurice. 1964a. "Eye and Mind." In The Primacy of Perception: And Other Essays on Phenomenological Psychology, the Philosophy of Art, History and Politics, edited by James M. Edie, translated by Carleton Dallery, 159-92. Evanston: Northwestern University Press.

1964b. L'Oeil et l'Esprit. Paris: Edition Gallimard.

.1964c.Signs. Translated by Richard McCleary. Evanston: Northwestern University Press.

1964d. "The Film and the New Psychology." In Sense and Non-Sense, translated by Hubert L. Dreyfus and Patricia Allen Dreyfus, 48-62. Evanston: Northwestern University Press.

1968. The Visible and the Invisible. Translated by Alphonso Lingis. Evanston: Northwestern University Press.

Roudinesco, Elisabeth. 1997. Jacques Lacan: Outline of a Life, History of a System of Thought. Translated by Barbara Bray. New York: Columbia University Press.

Waldenfels, Bernhard. 1993. "Interrogative Thinking: Reflections on Merleau-Ponty's Later Philosophy." In MerleauPonty in Contemporary Perspective, edited by Patrick V. Burke and Jan Van der Veken, 129:3-12. Phaenomenologica. Dordrecht: Springer. https://doi.org/10.1007/978-94-011-1751-7_1

Wiesing, Lambert. 2000. "Merleau-Pontys Phänomenologie des Bildes." In Maurice Merleau-Ponty und die Humanwissenschaften, edited by Regula Giuliani, 263-80. Munich: Wilhelm Fink Verlag.

\section{Biography}

Astrid Deuber-Mankowsky is Professor of Media Studies and Gender Studies at the Ruhr University Bochum. She has published extensively on feminist and queer theory, representation and mediality, media theory and philosophy as well as religion and modernism. She was a visiting scholar at UC Berkeley (2007), visiting professor at the Centre d'études du vivant, Université Paris VII - Diderot (2010), Max Kade Professor at Columbia University (2012), and Senior Fellow at the Internationales Kolleg für Kulturtechnikforschung und Medienphilosophie (IKKM) Weimar (2013). She is also an associate member of the Institute for Cultural Inquiry Berlin (ICI Berlin).

(c) 2017 Astrid Deuber-Mankowsky

(c) (ㅇ) Except where otherwise noted, this work is licensed under a Creative Commons Attribution-

(c) NonCommercial-ShareAlike 4.0 International License. 